\title{
Erratum to: The Influence of Scale Preferences on the Design of a Water Innovation: A Case in Dutch River Management
}

\author{
Heleen Vreugdenhil · Jill Slinger • Emiel Kater • \\ Wil Thissen
}

Published online: 21 September 2010

(C) Springer Science+Business Media, LLC 2010

Erratum to: Environmental Management

(2010) 46:29-43

DOI 10.1007/s00267-010-9524-0

The name of author Heleen Vreugdenhil was misspelled in the print and online versions of this article. It is presented correctly here.

The online version of the original article can be found under doi:10.1007/s00267-010-9524-0.

H. Vreugdenhil $(\bowtie) \cdot$ J. Slinger $\cdot$ W. Thissen

Faculty of Technology, Policy and Management,

Delft University of Technology, Jaffalaan 5, 2628 BX Delft,

The Netherlands

e-mail: h.s.i.vreugdenhil@tudelft.nl

E. Kater

Centre for Water and Society, Radboud University,

Nijmegen, The Netherlands 